\title{
The Significance of Adult Educators' Mentoring in the Application of Experiential and Participatory Teaching Techniques
}

\author{
Marios Koutsoukos $^{1}$, Konstantina Kiriatzakou $^{2}$, Iosif Fragoulis ${ }^{3} \&$ Efthymios Valkanos $^{2}$ \\ ${ }^{1}$ School of Pedagogical and Technological Education, ASPETE, Thessaloniki, Greece \\ ${ }^{2}$ Department of Educational and Social Policy, University of Macedonia, Thessaloniki, Greece \\ ${ }^{3}$ Hellenic Open University and School of Pedagogical and Technological Education, ASPETE, Athens, Greece \\ Correspondence: Marios Koutsoukos, School of Pedagogical and Technological Education, ASPETE, \\ Thessaloniki, Greece. E-mail: koutsoukos.marios@gmail.com
}

Received: August 6, 2020

doi:10.5539/ies.v14n1p46
Accepted: September 29, 2020

Online Published: December 26, 2020

URL: https://doi.org/10.5539/ies.v14n1p46

\begin{abstract}
The main objective of this research is to investigate the significance of adult educators' mentoring in the application of experiential and participatory teaching techniques. Bearing in mind that teaching techniques play a major role in adult education, emphasis is given on examining whether adult educators need mentoring for a more effective implementation of these techniques. More specifically, the study focuses on researching a sample of 337 educators' opinions concerning the extent they need mentoring and in which particularly teaching techniques. According to participants in the research, mentoring process has a significant impact on the effective use of experiential and participatory teaching techniques. Thus, research findings indicate that mentoring can become a useful tool for enhancing their knowledge and skills helping them become "better educators".
\end{abstract}

Keywords: teaching techniques, adult educators, mentoring, experiential and participatory learning

\section{Introduction}

\subsection{Adult Education and Characteristics of Adult Learners}

Over the last years, adult education has evolved significantly worldwide and has been institutionally diversified as a professional practice as well as a field of scientific study and research. The field of adult education is experiencing particular growth in many countries, as more and more adults participate in various learning processes, depending on their inclinations, interests and goals (Fehring \& Rodrigues, 2017).

It is a fact that adult learners have some specific characteristics, which greatly differentiate adult education from formal education (Knowles, Holton \& Swanson, 2015). More specifically, as most adult education programmes are not obligatory, participants are usually self motivated having a voluntary and conscious participation in the learning process. In addition, adult learners are in the middle and not at the beginning of an evolving development process and they have already established a considerable background of accumulated knowledge, experiences and values which can add to the learning process. Apart from that, adults participate in the respective learning processes with given intentions and expectations and usually have high demands from an educational program. Finally, adult learners usually have increased personal, family and social responsibilities, which affect their available time (Jarvis, 2010; Chugai, Terenko, \& Ogienko, 2017).

The characteristics of adult learners should also include their needs which actually affect more or less a learning process (Merriam \& Bierema, 2014). More specifically, adults have an increased need to understand the goals of an educational process, they need to feel "safe" and free from stress and anxiety, they need positive feedback, encouragement and reward and they have an internal need to feel that they belong to a team. In this context, adult educators' role is significant and in many cases crucial, as they come to choose and apply the teaching techniques that will form a positive and creative atmosphere in a learning process. Thus, adult educators' role is of vital importance in all theoretical approaches to adult education (Knowles, Holton \& Swanson, 2015; Jarvis, 2010). In any case, successful adult educators must take into consideration the characteristics and needs mentioned above and adapt their teaching methodology accordingly. In this regard, it is considered necessary to use specific teaching techniques geared to the adult learners' characteristics (Brookfield, 2013). 


\subsection{Teaching Techniques and Mentoring in Adult Education}

The teaching techniques applied in adult education should be experiential and participatory in order to stimulate learners' interest and ensure their active participation in the learning process (Chugai, Terenko, \& Ogienko, 2017). Such techniques engage adult learners, increase their interaction throughout the learning process and foster the development of critical thinking and communication skills, promoting at the same time learning through discovery and personal experience and leading to more integrated learning outcomes. Thus, the adult educator should use, depending on the occasion, techniques such as: discussion, working groups, demonstration, role play, brainstorming and case study.

In particular, discussion focuses on the exchange of views in the form of dialogue and the elaboration of an issue in depth, either between two participants or in working groups. As a teaching technique, discussion promotes creative dialogue, gives the opportunity to express personal opinions and arguments, activates learners' thinking and participation contributes to their socialization and strengthens the consolidation of respect for different views. Moreover, discussion is believed to be one of the most significant techniques, because of its potential to disperse power democratically around the learning group (Brookfield, 2013).

The working groups as an educational technique concern the division of all learners into sub-small groups, to which various tasks are assigned by the educator and at the end the works are presented in plenary. Such a technique encourages interaction, socialization and solidarity, while the educator acts as a "learning facilitator" supporting indirectly the whole process (Burke, 2011). Work groups, depending on the learning occasion, can be applied to several lessons and subjects.

In the demonstration technique, at the beginning the educator introduces an object or performs a specific action and subsequently learners are asked to repeat it under the educator's guidance. In demonstration, which is usually applied along with other techniques, practice gives impetus to experiential learning. Thus, it is an experiential and demonstrative technique that contributes to the consolidation of practical skills, stimulates interest and activates the senses of learners, strengthening "learning by doing".

Role playing can serve as an experiential teaching technique in which, under the educator's guidance, learners perform roles of a specific theme. Through role playing, an issue or problem under investigation can become a vivid experience for learners, activating their means of expression and developing their critical ability. In addition, this technique is a participatory and playful form of teaching that gives emphasis on the synergy of senses, enhances learners' imagination and contributes to their socialization (Dorgu, 2015).

Brainstorming is a teaching technique, in which learners bring to their mind preexisting notions spontaneously and effortlessly, by expressing keywords and terms connected to a central concept given by the educator. The educator notes the list of words on the board and subsequently uses them in the learning process, classifying each of them words with the learners' assistance. Apparently, this technique gives emphasis to the introduction and explanation of new terms and meanings, as well as to the recollection of notions formerly known to learners. Moreover, brainstorming gives emphasis on spontaneity and participation, promotes creative thinking, enhances critical thinking and gives a sense of heuristic-exploratory learning (Unin \& Bearing, 2016).

Case study, as a teaching technique, is the in-depth analysis and thorough investigation of a real or virtual case, problem, process or phenomenon in order to come to practical conclusions. Such a technique can be an extremely interesting motive for heuristic-exploratory learning, by focusing on the characteristics and specific features of a certain case. In adult education, case studies are often used in combination with other techniques such as discussion or working groups and activate learners' participation (Popil, 2011).

At this point, it should be noted that there is no "better" or "worse" teaching technique in advance, but adult educators should select and plan their use according to the special characteristics of each learning process. In any case, the selection and effective application of the above techniques is a complex issue, in which adult educators rarely have some mentoring support. Thus, most of the time adult educators are called upon to design and apply the various techniques on their own without the guidance of an experienced mentor.

Thus, over the last years, mentoring has emerged in the field of education, describing "a typical process in which a person with more knowledge and experience sets up a supportive role of supervising and facilitating thinking and learning in a less experienced person" (Fletcher \& Mullen, 2012; Roberts, 2000: 162). Particularly in adult education, establishing a good working relationship between the mentor and the mentee is a prerequisite for effective mentoring (Lankau \& Scandura, 2002). Literature review indicates that mentoring is varied in structure, form, context and content, but in any case scholars worldwide acknowledge its potential benefits for mentors, mentees and educational organizations (Knowles, Holton, \& Swanson, 2015; Fehring \& Rodrigues, 2017). Thus, it 
is acknowledged that by creating a mentality and practice of lifelong learning, mentoring can upgrade adult education (English, 2006; Ruginosu, 2014).

In the above context, the present study focused on specific research questions: a) to what extent do adult educators in their view need mentoring support in the design and implementation of these techniques? b) To what extent do they use these participatory techniques in practice? c) which specific techniques need more mentoring support?

\section{Method}

For the research's purposes a mix of qualitative and quantitative methods was used in order to provide a profound understanding of the main parameters of the issue (Robson, 2011; Babbie, 2001). Thus, ten semi-structured interviews were conducted with adult educators, selected intentionally for this purpose. The interviews had an average duration of one hour and were tape recorded. Primary data were collected between January and February 2020 and the useful conclusions deduced were utilized as an auxiliary research tool for the final definition of the questionnaire used at a later step. The interviews were structured on three thematic axes, investigating: a) personal characteristics and educators' profile, b) views concerning teaching techniques in adult education and c) perceptions on mentoring and its connection with application of experiential teaching techniques.

Next, in the phase of the quantitative research, a questionnaire was used, designed specifically for the purpose of this study. The questionnaire was formed taking into consideration the research's main objective, literature review and feedback provided by the interviews. It consisted of twenty six closed answer questions and the participants' level of agreement or disagreement with statements was assessed using a 5-point Likert-type scale questions (Robson, 2011; Vagias, 2006). The unit of analysis for the present research were active adult educators of various specialties (mathematicians, philologists, physicists, language teachers, biologists, agronomists and engineers) serving in educational organizations of Central Macedonia Prefecture. Initially, the questionnaire was pilot-tested in face-to-face meetings with thirty adult educators and redefined based on feedback received. Thus, the final survey was carried out between February and April 2020 and the questionnaire was sent via Google Forms to 408 adult educators. A total of 337 of them answered forming a satisfactory Response Rate (82.6\%), according to relevant literature (Groves, 2006). Statistical analysis was conducted using the Statistical Package for Social Sciences (SPSS v.25).

\section{Results}

The main finding of the qualitative research was participants' strong belief that mentoring can have a valuable contribution in the field of adult education not only for adult learners but also for adult educators providing them the necessary assistance concerning the application of experiential and participatory teaching techniques. Moreover, adult educators expressed the opinion that mentoring can become a useful tool for enhancing their knowledge and skills helping them become "better educators".

Statistical analysis of the questionnaires initially contributed to the formation of the respondents' profile (Table 1). In particular, out of the 337 participants, 209 were female (62\%) and 128 male (38\%). As far as age distribution is concerned, at the time when the research was conducted, 152 educators were between 46-55 (45.1\%), 147 were between 36-45 and 38 were between 25-35 (11.3\%) (Table 1). Regarding postgraduate studies, 192 respondents hold a Master Degree (57\%) while 18 hold a Ph.D. (5.3\%) (Table 1). Another important parameter in the educators' profile is work experience. In this research, out of the 337 participants 181 had 1-10 years teaching experience in adult education (53.7\%), 125 had 11-20 years (37.1\%), 28 had $21-30$ years $(8.3 \%)$ while only 3 of them $(0.9 \%)$ had an over 30 years of teaching in adult education (Table 1). Finally, the vast majority of the respondents, 248 out of 337 , had attended training courses in adult education (73.6\%), while 89 of them had not attended any training (26.4\%).

Table 1. Adult educators' profile

\begin{tabular}{ll}
\hline Sex & Male: $128(38 \%)$ Female: $209(62 \%)$ Total: $337(100 \%)$ \\
\hline \multirow{2}{*}{ Age distribution } & 25-35 36-45 46-55 Total \\
& $38(11.3 \%) 147(43.6 \%) 152(45.1 \%) 337(100 \%)$ \\
\hline \multirow{2}{*}{ Postgraduate studies } & Master Ph.D. Total \\
& Yes: $192(57 \%)$ No: $145(43 \%)$ Yes: $18(5.3 \%)$ No: $319(94.7 \%) 337(100 \%)$ \\
\hline Years teaching & $1-1011-2021-30>30$ Total \\
in adult education & $181(53.7 \%) 125(37.1 \%) 28(8.3 \%) 3(0.9 \%) 337(100 \%)$ \\
\hline Training in adult education & Yes: $248(73.6 \%)$ No: $89(26.4 \%)$ Total: $337(100 \%)$ \\
\hline
\end{tabular}


Subsequently, using a five-point Likert-type scale ranging from "not at all" to "to a very great extent", research focused on investigating to what extent adult educators need mentoring in order to use efficiently participatory and experiential teaching techniques. Thus, 116 respondents (34.4\%) pointed out that they need mentoring to a great extent and 98 respondents $(29.1 \%$ ) to a very great extent (Table 2). On the contrary, only 36 of the respondents $(10.7 \%)$ believed that mentoring is needed to a small extent while 69 believed mentoring is needed to a moderate extent (20.5\%) (Table 2).

Table 2. To what extent adult educators need mentoring in order to use efficiently participatory and experiential teaching techniques

\begin{tabular}{ccccccc}
\hline Not at all & To a small extent & To a & moderate extent & To a great extent & To a very great extent & Total \\
\hline $18(5.3 \%)$ & $36(10.7 \%)$ & $69(20.5 \%)$ & $98(29.1 \%)$ & $116(34.4 \%)$ & $337(100 \%)$ \\
\hline
\end{tabular}

Next, participants were asked to outline to what extent they use certain participatory and experiential teaching techniques during adult learning procedures. Taking into consideration the interviews of the qualitative research and the relevant literature review, the research focused on six teaching techniques: discussion, work groups, demonstration, role playing, brainstorming and case study (Table 3). Thus, discussion seems to be a very popular technique among educators as 225 of the respondents $(66.8 \%)$ use it to a very great extent while 81 use it to a great extent (24\%) (Table 3). Another popular technique is work groups which are used by 149 participants in this research to a very great extent $(55.8 \%)$ and by 112 participants to a great extent $(33.2 \%)$ (Table 3$)$. On the other hand, the teaching technique of demonstration is used to a very great extent by 59 respondents $(17.5 \%)$, to a great extent by $90(26.7 \%)$, to a moderate extent by $105(31.2 \%)$, to a small extent by $54(16 \%)$ while 29 respondents (8.6\%) claimed they don't use at all this technique (Table 3).

Role playing is used to a very great extent by 61 adult educators $(18.1 \%)$, to a great extent by $82(24.3 \%)$, to a moderate extent by $91(27 \%)$, to a small extent by 61 (18.1\%) and not at all by 42 (12.5\%) (Table 3). Brainstorming, a teaching technique which promotes spontaneity and critical thinking, is used to a very great extent by 149 respondents (44.2\%), to a great extent by $112(33.2 \%)$, to a moderate extent by $55(16.3 \%)$, to a small extent by $19(5.6 \%)$ and not at all only by $2(0.6 \%)$ (Table 3). Finally, 102 adult educators use case study as a teaching technique to a great extent (30.3\%), 113 use it to a great extent (33.5\%), 70 to a moderate extent $(20.7 \%)$, 38 to a small extent (11.3\%) and 14 do not use it at all (4.2\%) (Table 3$)$.

Table 3. To what extent adult educators use the following teaching techniques

\begin{tabular}{ccccccc}
\hline $\begin{array}{c}\text { Teaching } \\
\text { Technique }\end{array}$ & Not at all & To a small extent & To a moderate extent & To a great extent & To a very great extent & Total \\
\hline Discussion & $0(0 \%)$ & $8(2.4 \%)$ & $23(6.8 \%)$ & $81(24 \%)$ & $225(66.8 \%)$ & $337(100 \%)$ \\
Work groups & $10(2.9 \%)$ & $19(5.6 \%)$ & $55(16.3 \%)$ & $112(33.2 \%)$ & $149(55.8 \%)$ & $337(100 \%)$ \\
Demonstration & $29(8.6 \%)$ & $54(16 \%)$ & $105(31.2 \%)$ & $90(26.7 \%)$ & $59(17.5 \%)$ & $337(100 \%)$ \\
Role playing & $42(12.5 \%)$ & $61(18.1 \%)$ & $91(27 \%)$ & $82(24.3 \%)$ & $61(18.1 \%)$ & $337(100 \%)$ \\
Brainstorming & $2(0.6 \%)$ & $19(5.6 \%)$ & $55(16.3 \%)$ & $112(33.2 \%)$ & $149(44.2 \%)$ & $337(100 \%)$ \\
Case study & $14(4.2 \%)$ & $38(11.3 \%)$ & $70(20.7 \%)$ & $113(33.5 \%)$ & $102(30.3 \%)$ & $337(100 \%)$ \\
\hline
\end{tabular}

Finally, as indicated below (Table 4), participants were asked to demarcate to what extent they need mentoring in the application of each particular teaching technique. In particular, as far as discussion is concerned, 142 adult educators need mentoring to a very great extent $(42.1 \%), 88$ to a great extent $(26.1 \%)$, and 103 to a moderate extent $(30.6 \%)$. Mentoring seems to be necessary for educators also in the implementation of work groups, as 123 respondents need it to a very great extent $(36.6 \%), 139$ to a great extent $(41.2 \%)$ and 56 to a moderate extent $(16.6 \%)$. Moreover, 112 respondents need mentoring for the teaching technique of demonstration to a great extent (33.2\%), 143 to a great extent (42.5\%) and 77 to a moderate extent $(22.8 \%)$. As far as role playing is concerned, 182 respondents need mentoring to a very great extent (54\%) for its effective application, 82 to a great extent $(24.3 \%)$ and 70 to a moderate extent $(20.8 \%)$. According to 94 adult educators, mentoring is needed also in the application of brainstorming to a very great extent $(27.9 \%)$, according to 97 educators is needed to a great extent $(28.8 \%)$ and according to 142 to a moderate extent $(42.1 \%)$. Finally, regarding case study, 134 respondents need mentoring to a very great extent (39.8\%), 108 to a great extent (32\%) and 86 to a moderate extent $(25.5 \%)$ (Table 4). 
Table 4. To what extent adult educators need mentoring in the application of each particular teaching technique

\begin{tabular}{|c|c|c|c|c|c|c|}
\hline $\begin{array}{l}\text { Teaching } \\
\text { Technique }\end{array}$ & Not at all & To a small extent & To a moderate extent & To a great extent & To a very great extent & Total \\
\hline Discussion & $4(1.2 \%)$ & $0(0 \%)$ & $103(30.6 \%)$ & $88(26.1 \%)$ & $142(42.1 \%)$ & $337(100 \%)$ \\
\hline Work groups & $7(2 \%)$ & $12(3.6 \%)$ & $56(16.6 \%)$ & $139(41.2 \%)$ & $123(36.6 \%)$ & $337(100 \%)$ \\
\hline Demonstration & $0(0 \%)$ & $5(1.5 \%)$ & $77(22.8 \%)$ & $143(42.5 \%)$ & $112(33.2 \%)$ & $337(100 \%)$ \\
\hline Role playing & $0(0 \%)$ & $3(0.9 \%)$ & $70(20.8 \%)$ & $82(24.3 \%)$ & $182(54 \%)$ & $337(100 \%)$ \\
\hline Brainstorming & $0(0 \%)$ & $4(1.2 \%)$ & $142(42.1 \%)$ & $97(28.8 \%)$ & $94(27.9 \%)$ & $337(100 \%)$ \\
\hline Case study & $2(0.6 \%)$ & $7(2.1 \%)$ & $86(25.5 \%)$ & $108(32 \%)$ & $134(39.8 \%)$ & $337(100 \%)$ \\
\hline
\end{tabular}

\section{Discussion}

The use of participatory and experiential teaching techniques in adult education is of major importance because it greatly affects parameters such as the activation of learners, the creation of a positive learning environment, the achievement of learning objectives and ultimately the successful outcome of a learning process (Brookfield, 2013; Courau, 2000). In this context, the role of adult educators, who are called upon to apply the respective teaching techniques, is crucial. Taking into consideration adult learners' characteristics and needs, educators must adjust their teaching methodology adopting a more learner centred approach. From this point of view, educators' mentoring is regarded as having considerable potential to make a significant contribution to adult learning (English, 2006).

The research presented in this paper focused on investigating the views of 337 active adult learners, serving in educational institutions in North Greece. Using a combination of qualitative (interviews) and quantitative (questionnaire) methodology, the research concluded that educators' mentoring is a process which can enhance the value of educational experience by making it responsive to modern adult education needs and communicating the significance of lifelong learning (English, 2006).

Moreover, discussion and work groups seem to be the most popular teaching techniques among respondents, used to a great extent in learning process, as they strengthen interaction between educators and learners and establish a favorable learning atmosphere.

Furthermore, the present study investigated whether active adult educators need the mentoring process and in which particularly teaching techniques. The results indicated that respondents believe they need mentoring to a great extent, as a process that will enhance them in the effective use of participatory and experiential teaching techniques. In particular, educators responded that mentoring is necessary for the more effective implementation of role playing and work groups.

The findings of this research highlight the significance of mentoring in modern adult education and the practical implications offer interesting insights not only for adult educators, but also for educational policy makers, public and private educational organizations staff and researchers in the field of adult education. Thus, the findings provide a starting point for future research on various aspects of this issue.

\section{Acknowledgements}

The authors would like to thank the 337 participating educators for their cooperation and willingness to respond to this research. In addition, the authors are grateful to the editor and the reviewers of this Journal for their valuable feedback on an earlier version of this manuscript.

\section{References}

Babbie, E. (2001). The Practice of Social Research (9th ed.). Belmont, CA: Wadsworth Thomson.

Brookfield, S. D. (2013). Powerful techniques for teaching adults. San Francisco: Jossey-Bass.

Burke, A. (2011). Group Work: How to Use Groups Effectively. Journal of Effective Teaching, 11(2), 87-95.

Chugai, O., Terenko, O., \& Ogienko, O. (2017). Methods that work: Best Practices of Adult Educators in the USA. Advanced Education, 8, 72-77. https://doi.org/10.20535/2410-8286.109216

Courau, S. (2000). The basic tools of the adult educator (Moutsopoulou, Trans.). Athens: Metehmio.

Dorgu, T. E. (2015). Different Teaching Methods: A panacea for effective curriculum implementation in the classroom. International Journal of Secondary Education, Special Issue: Teaching methods and learning styles in education, 3(6), 77-87. https://doi.org/10.11648/j.ijsedu.s.2015030601.13 
English, L. (2006). An Adult Learning Approach to Preparing Mentors and Mentees. Mentoring \& Tutoring: Partnership in Learning, 7(3), 195-202. https://doi.org/10.1080/1361126990070302

Fehring, H., \& Rodrigues, S. (2017). Teaching, Coaching and Mentoring Adult Learners. Lessons for professionalism and partnership. New York: Routledge. https://doi.org/10.4324/9781315660028

Fletcher, S., \& Mullen, C. (2012). The SAGE Handbook of Mentoring and Coaching in Education. London: Sage.

Groves, R. M. (2006). Nonresponse rates and nonresponse bias in household surveys. Public Opinion Quarterly, 70(5), 646-675. https://doi.org/10.1093/poq/nfl033

Jarvis, P. (2010). Adult education and lifelong learning. Theory and practice (4th ed.). London: Routledge.

Knowles, M., Holton, E., \& Swanson, R. (2015). The Adult Learner. The definitive classic in adult education and human resource development (8th ed.). London: Routledge. https://doi.org/10.4324/9781315816951

Lankau, M. J., \& Scandura, T. A. (2002). An investigation of personal learning in mentoring relationships: Content, antecedents and consequences. Academy of Management Journal, 45(4), 779-790. https://doi.org/10.2307/3069311

Merriam, S., \& Bierema, L. (2014). Adult Learning. Linking Theory and Practice. San Francisco: Jossey-Bass

Popil, I. (2011). Promotion of critical thinking by using case studies as teaching method. Nurse Education Today, 31, 204-207. https://doi.org/10.1016/j.nedt.2010.06.002

Roberts, A. (2000). Mentoring revisited: A phenomenological reading of the literature. Mentoring and Tutoring, 8(2), 145-170. https://doi.org/10.1080/713685524

Robson, C. (2011). Real world research (3rd ed.). Chichester: John Wiley \& Sons Ltd.

Ruginosu, A. T. (2014). Organizing Adult Mentoring Activities at European Level. Procedia-Social and Behavioral Sciences 142, 536-541. https://doi.org/10.1016/j.sbspro.2014.07.662

Unin, N., \& Bearing, P. (2016). Brainstorming as a way to approach student-centered learning in the ESL classroom. Procedia-Social and Behavioral Sciences, 224, 605-612. https://doi.org/10.1016/j.sbspro.2016.05.450

Vagias, W. M. (2006). Likert-Type Scale Response Anchors. Clemson International Institute for Tourism. Retrieved from http://www.clemson.edu/centers-institutes/tourism/documents/sample-scales.pdf

\section{Copyrights}

Copyright for this article is retained by the author(s), with first publication rights granted to the journal.

This is an open-access article distributed under the terms and conditions of the Creative Commons Attribution license (http://creativecommons.org/licenses/by/4.0/). 